\title{
Realization of genetic potential of productivity of cows of Ukrainian black-motley dairy breed depending on season of calving in conditions of Steppe zone
}

\author{
V. Kozyr, \\ academician of NAAS, doctor of agricultural sciences \\ Institute of grain crops NAAS
}

The purpose. To investigate influence of season of calving of cows upon realization of genetic potential of their productivity. Methods. Analysis of variance of attributes of milk yield, correlative interaction of breed with amount of lactations. Results. Implementation of genetic potential of productivity of cows of Ukrainian black-motley dairy breed in conditions of steppe zone of Ukraine with optimum toughness and stability of lactation depends on season of their calving. These indexes can be used also as criterion of conformity of ecological conditions to that genotype, and divergence specifies an opportunity of the subsequent selection operation. Conclusions. In steppe zone of Ukraine the genetic potential of productivity with optimum toughness and stability of lactation is more full manifested at calving cows of Ukrainian black-motley dairy breed in I and IV quarters of year.

Key words: breed, season, calving, potential, productivity.

The problem of providing Ukraine's population with milk, unfortunately, remains critical [6]. To solve it, the stud farms and farms, scientists and practitioners, government agencies and private agro-formations using various techniques of increasing production through modern methods, including increasing the genetic potential productivity of cows [3]. Acting approaches, improvement of dairy cattle is mainly on large tracts of livestock breeding methods welcomesthe [9]. Breeding work in micro-population gene pool stud requires different techniques. Further progress of the industry has resulted in not only preserving the best parts and increase of productivity genetic potential of native breeds. A comprehensive solution to this problem has both theoretical and practical importance, therefore, is relevant for the programming and control selection and technological processes in dairy cattle [1, 8].

Material and methods research. The basic business was the breeding of Ukrainian black-speckled dairy breed "Chumaky" in the Dnipropetrovsk region. To assess the basic economic-useful signs pagola used in conventional animal husbandry techniques. Animals were kept in indoor loose housing on deep litter with free access to the backyard-feeding area, feeding on the VIT standards for traditional steppe zone fodder (hay and silage from alfalfa, silage corn, feed), milking on the "Carousel".

The results of the research. The main features of dairy cattle is the milk yield per lactation, quantity of milk fat and protein in milk and their output. It is known that the degree of realization of genetic potential productivity due to genotipurile characteristics of animals, methods of breeding and technological factors - the conditions of feeding, housing, rearing of rearing [4].

At the same time, in practice, insufficiently takes into account the effect of a number of other paratypical factors such as season (month, quarter) calving and uniformity of lactation curve, which play a significant role in the productivity of animals. Therefore, we studied milk yield during three lactation by season of calving (Table. 1). 
1. Milk yield per lactation depending on calving season,

\begin{tabular}{|l|l|l|l|}
\hline \multirow{2}{*}{$\begin{array}{l}\text { The calving at } \\
\text { quarter of the } \\
\text { year. }\end{array}$} & \multicolumn{3}{|l|}{ Milk yield per lactation } \\
\cline { 2 - 4 } & 1 & 2 & 3 \\
\hline I & $4723 \pm 26,3$ & $4459 \pm 19,9$ & $4504 \pm 17,9$ \\
\hline II & $4253 \pm 19,2$ & $4429 \pm 29,2$ & $4603 \pm 20,6$ \\
\hline III & $4301 \pm 27,1$ & $4437 \pm 29,0$ & $4637 \pm 22,8$ \\
\hline IV & $4485 \pm 17,7$ & $4725 \pm 16,1$ & $4427 \pm 21,0$ \\
\hline
\end{tabular}

Established that the greatest yield of milk in cows must be lactating at the hotel in the first quarter. In second lactation no significant difference of milk yield between the seasons (with the exception of the maximum score in the fourth quarter). However, the effect of season of calving on annual performance was the same place that gives grounds to conclude that in the Ukrainian black-spotted dairy breed the degree of "sensitivity of the environment" decreases with the age of cows as more clearly shown the effect of genotypic factors [7]. The difference in capacity lactational activity occurs under the influence of the interaction of genetic and technological factors (genotype $x$ technology). To determine their impact, we performed a calculation traffictornado dispersion of the complex, where the species (A), number of lactations (In) and month of lactation (C). The results of the analysis of variability of the trait of milk yield per lactation (tab.2) indicate that the greatest influence breed animals (53,1\% factoralso dispersion), and season (month of lactation - $10.0 \%$ ).

\section{Analysis of variance trait milk yield per lactation}

\begin{tabular}{|l|l|l|l|l|l|l|}
\hline $\begin{array}{l}\text { Source of } \\
\text { variation }\end{array}$ & $\begin{array}{l}\text { Sum of } \\
\text { squares }\end{array}$ & $\begin{array}{l}\text { The degree } \\
\text { of freedom }\end{array}$ & $\begin{array}{l}\text { mean } \\
\text { square }\end{array}$ & F-criterion & $\begin{array}{l}\text { p- } \\
\text { significance }\end{array}$ & $\begin{array}{l}\text { Part of the } \\
\text { influence, \% }\end{array}$ \\
\hline A-breed & 1324752 & 1 & 1324752 & 98,613 & 0,0000 & 53,1 \\
\hline B-lactation & 190055 & 2 & 95028 & 7,074 & 0,0009 & 7,6 \\
\hline C-month & 249242 & 11 & 22658 & 1,687 & 0,0723 & 10,0 \\
\hline AB & 120659 & 2 & 60330 & 4,491 & 0,0116 & 4,8 \\
\hline AC & 132258 & 11 & 12023 & 0,895 & 0,5449 & 5,3 \\
\hline BC & 169542 & 22 & 7706 & 0,574 & 0,9414 & $6,8 \%$ \\
\hline ABC & 307889 & 22 & 13995 & 1,042 & 0,4092 & $12,3 \%$ \\
\hline
\end{tabular}

Discovered also a high interaction of all factors that were studied ( $A B C 12.3$ percent). Their individual impact significant enough to breed and the number of lactations $(P<0.01)$ and was at the level of $P<0,07$ for month of lactation.

In the study of milk productivity of cows depending on genetic factors and season of calving, we have established various indicators of realization of the genetic potential for the trait "milk yield per lactation) (Table. 3).

3. The genetic potential of milk productivity depending on genotype and season of calving

\begin{tabular}{|l|l|l|l|}
\hline Lactation & $\begin{array}{l}\text { The calving at } \\
\text { quarter of the year. }\end{array}$ & Asimptota & $\begin{array}{l}\text { The forecast for the first 3 } \\
\text { months. }\end{array}$ \\
\hline \multirow{5}{*}{ I } & I & 5000,0 & 4983,3 \\
\cline { 2 - 4 } & II & 4900,0 & 4891,1 \\
\cline { 2 - 4 } & III & 4800,0 & 4828,9 \\
\cline { 2 - 4 } & IV & 5150,0 & 4963,3 \\
\hline II & I & 4650,0 & 5063,3 \\
\cline { 2 - 4 } & II & 4650,0 & 5850,0 \\
\cline { 2 - 4 } & III & 4650,0 & 6013,3 \\
\hline
\end{tabular}




\begin{tabular}{|l|l|l|l|}
\hline & IV & 5200,0 & 4765,6 \\
\hline \multirow{4}{*}{ III } & I & 4900,0 & 4978,9 \\
\cline { 2 - 4 } & II & 4900,0 & 5127,8 \\
\cline { 2 - 4 } & III & 4970,0 & 5464,5 \\
\cline { 2 - 4 } & IV & 4700,0 & 5383,3 \\
\hline
\end{tabular}

Largest asymptote (calculated for 10 months of lactation - 305 days) genetic potential ranged from 4650 to $5200 \mathrm{~kg}$ of milk and $4829,8 \ldots 6013,3 \mathrm{~kg}$ - based on the forecast based on the average for the first 3 months of lactation. Significantly higher genetic productivity potential identified regardless of the number of lactations in first, second or third quarter.

In the first lactation showed more fully the genetic potential of cows, which resterilise in the third and first quarters (respectively 98 and $95 \%$ ), second lactation in the fourth quarter (99\%), the third - in the first and second quarters $(90 \%)$.

Genetic potential productivity, determined by the values of the asymptotes is mainly characterized by the actually received expectations, it is more informative to predict the maximum milk productivity by creating optimal conditions of feeding and housing [5], that is, the genetic potential and the degree of its implementation, together with hereditary factors have an impact on the paratypical [2].

You should also consider the importance of working "breed $x$ number of lactation" $(P<0.001)$, which influences the level of realization of genetic potential.

Recently in zootechnical science, increased attention to the adaptive value of genotypes, which characterizes their ability to maintain the system performance under changes in environmental conditions and influenced by ontogenetic factors. Criteria that accept parameters of plasticity and stability of lactation (Tab. 4).

\section{Indicators of plasticity and stability of yield for $\mathbf{3 0 5}$ days of lactation depending on calving month cows}

\begin{tabular}{|c|c|c|c|c|c|c|c|c|c|}
\hline \multirow{3}{*}{$\begin{array}{l}\text { The month } \\
\text { of calving }\end{array}$} & \multicolumn{9}{|c|}{ Lactation } \\
\hline & \multicolumn{3}{|c|}{1} & \multicolumn{3}{|l|}{ II } & \multicolumn{3}{|l|}{ III } \\
\hline & $\mathrm{b}$ & $\sigma$ & $r$ & $\mathrm{~b}$ & $\sigma$ & $r$ & $\mathrm{~b}$ & $\sigma$ & $r$ \\
\hline January & 1,000 & 126,42 & 0,496 & 0,110 & 90,84 & 0,113 & 0,673 & 85,34 & $0,698^{* *}$ \\
\hline February & 2,163 & 179,70 & $0,754^{* *}$ & 1,198 & 117,77 & $0,948^{* * *}$ & 0,347 & 70,35 & 0,437 \\
\hline March & 0,358 & 97,57 & 0,230 & 1,169 & 124,40 & $0,875^{\star \star *}$ & 1,204 & 126,59 & $0,841^{* * *}$ \\
\hline April & 1,506 & 121,18 & $0,779^{* *}$ & 1,854 & 192,32 & $0,898^{\star * *}$ & 0,863 & 102,77 & $0,743^{* *}$ \\
\hline May & 1,045 & 76,23 & $0,859^{* * *}$ & 0,936 & 100,66 & $0,866^{\star * \star}$ & 0,785 & 82,81 & $0,838^{* * *}$ \\
\hline Juny & 1,210 & 112,81 & $0,672^{* *}$ & 1,556 & 163,89 & $0,845^{\star \star \star}$ & 1,251 & 138,09 & $0,802^{* *}$ \\
\hline July & 1,289 & 127,82 & $0,632^{* *}$ & 1,909 & 192,51 & $0,924^{* \star *}$ & 1,250 & 120,12 & $0,921^{* * *}$ \\
\hline August & 1,202 & 179,94 & 0,419 & 0,823 & 100,78 & $0,761^{* *}$ & 1,328 & 148,47 & $0,791^{* *}$ \\
\hline September & $-0,449$ & 130,26 & $-0,216$ & 1,770 & 181,74 & $0,907^{* * *}$ & 1,085 & 113,02 & $0,849^{* * *}$ \\
\hline October & 0,290 & 49,78 & 0,365 & 0,591 & 105,68 & $0,521^{*}$ & 0,795 & 89,62 & $0,785^{\star \star}$ \\
\hline November & 1,376 & 112,72 & $0,765^{* *}$ & 0,215 & 95,19 & 0,210 & 1,306 & 126,47 & $0,913^{\star \star *}$ \\
\hline December & 1,010 & 79,85 & $0,793^{* *}$ & $\begin{array}{l}- \\
0,131\end{array}$ & 60,98 & $-0,200$ & 1,112 & 31,72 & $0,751^{* *}$ \\
\hline
\end{tabular}


Our studies have shown that the lowest levels of plasticity (b) shown by the cows in the third lactation in January $(0,673)$, February $(0,347)$ and October $(0,795)$, and stability $(\sigma)-$ in December, the third and second lactation (respectively, 31, 72 and to $60.98 \mathrm{~kg}$ ) and October first of 49.78. The correlation coefficient $(r)$ between actual yield and the calculated theoretical level regression have a significant value at high and medium ductility $(0,754$ to $0,973, P<0.001)$.

In General, it should be noted that the ductility and stability of lactation together with an assessment of the environment and the sensitivity of genotype on calving season, can also be used as a criterion of compliance of environmental conditions the genetic potential of milk productivity of cows. At the same time, the presence of significant differences in these indicators points to the possibility of subsequent breeding to obtain animals with high stability and average plasticity.

\section{Conclusion}

Climate, feed and process conditions of the steppe zone of Ukraine to support a more full expression of genetic potential productivity with optimal flexibility and stability at the hotel of lactation of cows of the Ukrainian black-motley dairy breed in the first and fourth quarters of the year.

\section{Bibliography}

1. Барабаш В.И. Селекция с учетом биоэнергетической оценки коров// Зоотехния. -2000 . - №4. - C. 20-24.

2. Басовский Н.3. Взаимодействие генотипа со средой в популяциях молочного скота // Вісник аграрної науки. - 1997. - №12. - С. 40-44

3. Єфіменко М.Я., Подоба Б.Є., Антоненко В.І., Дзіцюк В.В. Генетичний моніторинг при консолідації порід молочної худоби// Розведення і генетика тварин. - К.: Аграрна наука. - 1999. Вип. 31-32. - С. 75-77.

4.Зубець М.В., Буркат В.П., Єфіменко М.Я., Полупан Ю.П., Кругляк А.П. Практична результативність новітніх теорій та методологій селекції // Вісник аграрної науки. - 2000. - № 12. C. 73-78.

5. Мельник Ю.Ф., Микитас Р.Є. Удосконалення моделювання і прогнозування молочної продуктивності в скотарстві // Таврійський науковий вісник. - Херсон: Айлант. - 2002. - Вип. 3. - С. 86-98.

6. Нижник О.М. Продовольча безпека в Україні: стан та проблеми вирішення // Стратегія економічного розвитку України: Наук.зб.- К.: КНЕУ. 2001. - вип. 4. - С. 163-173.

7. Петренко И.П., Винничук Д.Т. Подбор животных и качество потомства // Вісник аграрної науки. - 1995. - №6. - С. 14-19.

8. Рубан С.Ю. Система комплексної оцінки великої рогатої худоби // Вісник аграрної науки. 2001. - №3. - С. 40-47.

9. Эйснер Ф.Ф. Генетические основы крупномасштабной селекции молочного скота // Повышение генетического потенциала молочного скота. - М.: Агропромиздат, 1986. - С. 9-18. 